\title{
TINGKAT KEPUASAN KEPEMIMPINAN KETUA YAYASAN SERI AMAL MEDAN
}

\author{
Silveria Purba \\ Sekretaris Pengurus Yayasan Seri Amal Medan
}

\begin{abstract}
Abstrak
Penelitian ini bertujuan untuk mengukur tingkat kepuasan kepemimpinan Ketua Yayasan Seri Amal Medan. Jenis penelitian ini termasuk deskriptif kuantitatif. Penelitian dilakukan pada bulan Nopember 2020 kepada Kepala Sekolah yang di unit TK, SD, SMP, dan SMA yang dikelola Yayasan Seri Amal Medan, Jalan Hayam Wuruk 11 Medan. Jumlah responden adalah 11 orang. Data dikumpulkan dengan menggunakan angket dengan lima option yang berjumlah 35 pernyataan. Data dianalisis dengan mentabulasi dan menjumlahkan setiap pilihan maupun secara keseluruhan dengan kriteria berikut: 90-100 (sangat baik), 80-89 (baik), 65-79 (cukup baik), di bawah 65 (kurang). Tingkat kepuasan kepemimpinan Ketua Yayasan Seri Amal Medan oleh Kepala Sekolah di unit TK, SD, SMP, dan SMA yang dikelola Yayasan Seri Amal Medan tergolong sangat baik yaitu skor 90,44.
\end{abstract}

\section{Kata kunci: Kepuasan, Kepemimpinan}

\begin{abstract}
This study aims to measure the level of leadership satisfaction of the chairman of the Seri Amal Foundation Medan. This type of research is descriptive quantitative. The research was carried out in November 2020 to school principals in kindergarten, elementary, junior high and high school units managed by the Medan Amal Series Foundation, Jalan Hayam Wuruk 11 Medan. The number of respondents is 11 people. Data were collected using a questionnaire with five options totaling 35 statements. The data were analyzed by tabulating and adding up each choice or as a whole with the following criteria: 90-100 (very good), 8089 (good), 65-79 (good enough), under 65 (poor). The level of satisfaction of the leadership of the Head of the Seri Amal Medan Foundation by the Principal of the Kindergarten, Elementary, Middle School and High School units managed by the Medan Seri Amal Foundation is classified as very good, namely a score of 90.44 .
\end{abstract}

\section{Key Word: Satisfaction, Leadership}

\section{PENDAHULUAN}

Pemimpin dan kepemimpinan sangat penting dalam keberadaan serta kemajuan suatu lembaga atau organisasi. Dengan pemimpin dan kepemimpinan yang baik, sebuah lembaga akan menjadi produktif dari segi kualitas dan kuantitas dalam kemajuan dan pengembangan organisasi tersebut sesuai dengan tujuan yang sudah ditetapkan. Untuk mencapai hal tersebut dibutuhkan pemimpin yang memiliki kompetensi dan performansi yang baik. Seorang pemimpin harus memiliki kemampuan konseptual, teknis, manajerial, sosial, dan kemampuan kepribadian yang baik. Dengan kemampuan ini diharapkan dapat mengelola dan memberdayakan semua hal dalam organisasi itu (sumber daya manusia, keuangan, fasilitas) secara baik, produktif, efektif, dan efisien. 
Yayasan Seri Amal Medan merupakan salah satu yayasan yang pengelolaannya ada dalam naungan Kongregasi Suster-Suster Santo Yosef (KSSY). Yayasan ini berdiri pada tanggal 7 Oktober 1958 sebagai salah satu sarana untuk mewujudkan spritualitas KSSY melalui karya pendidikan dengan motto Quaerite Veritate (carilah kebenaran). YSA mengelola 18 unit sekolah mulai Paud/TK, SD, SMP, dan SMA yang ada di Medan, Sidikalang, Parsoburan, Palangkaraya, dan Pangkalan Brandan dengan puluhan ribu siswa. Selaras dengan spritualitas dan motto tersebut, ada visi Yayasan Seri Amal yaitu "Terselenggaranya Pendidikan dan Pembinaan yang terintergrasi melalui penghargaan dengan memberdayakan siswa dan peserta bina berdasarkan ajaran dan moral Katolik demi terwujudnya peran serta mereka kelak di dalam masyarakat, bangsa, dan gereja". Misi untuk mencapai visi itu adalah (1) menyelenggarakan proses pembelajaran dan bimbingan ilmu yang bermutu tinggi pada setiap jenjang sekolah dan unit kegiatan, (2) melaksanakan upaya-upaya pemberdayaan staf dan siswa melalui pelatihan-pelatihan dan skill training, (3) memajukan kehidupan rohani melalui pendidikan agama, retret dan pembinaan iman, (4) mempromosikan kepekaan dan penghargaan keutuhan alam dan lingkungan, dan (5) menyediakan dana dan fasilitas melalui berbagai kegiatan dan dari sponsor.

Untuk mencapai visi dan misi Yayasan Seri Amal Medan dibentuk kepengurusan yayasan sesuai dengan Undang-undang RI Nomor 16 tahun 2001 dan Undang-undang RI Nomor 28 tahun
2004 tentang yayasan. Dalam undangundang tersebut tertulis bahwa organ yayasan itu terdiri dari Pembina, Pengawas, dan Pengurus. Dalam pasal 32 butir (3) disebutkan bahwa susunan Pengurus sekurang-kurangnya terdiri atas (a) seorang ketua, (b) seorang sekretaris, dan (c) seorang bendahara.

Pengelola ril sebuah yayasan adalah pengurus yayasan dan kunci keberhasilan pencapaian tujuan yayasan adalah ketua yayasan. Dari segi manajemen, ketua yayasan berfungsi sebagai top manajemen yang sangat berperan dalam melakukan planning, organizing, staffing, directing, commanding, controlling, dsb. Sebagai bahan masukan dan perbaikan dalam menjalankan fungsi kepemimpinan dalam sebuah lembaga maka perlu dilakukan pengukuran tingkat kepuasan kepemimpinan dalam sebuah lembaga agar dapat dijaga dan ditingkatkan kualitas/ kuantitas kepuasan pelanggan. Kegiatan ini berkaitan dengan pengukuran tingkat kepuasan kepemimpinan Ketua Yayasan Seri Amal Medan tahun 2020.

\section{TINJAUAN PUSTAKA}

\section{A. Konsep Kepuasan}

Bahasa Inggris kata kepuasan adalah satisfaction. Kata ini berasal dari bahasa Latin yaitu satis artinya cukup baik dan factio artinya melakukan atau membuat. Dengan demikian dapat diartikan sebagai usaha pemenuhan sesuatu.Dalam Kamus Besar Bahasa Indonesia, puas berarti (a) merasa senang dan (b) lebih dari cukup; kepuasan berarti perihal bersifat puas; kesenangan; kelegaan, dsb. (2008: 1110) Waridin dan

\author{
p-ISSN 2648-8600 \\ e-ISSN 2745-410X \\ Volume 3 Nomor 2 Desember2020
}


Masrukhin (2006) mengatakan bahwa kepuasan sebagai tingkat perasaan seseorang setelah membandingkan kinerja atau hasil yang dirasakannya dengan harapannya. Apabila kinerja di bawah harapan maka pelanggan akan sangat kecewa, demikian sebaliknya.

\section{B. Konsep Kepemimpinan}

Dubrin (2005) mengemukakan bahwa kepemimpinan adalah upaya mempenaruhi banyak orang melalui komunkasi untuk mencapai tujuan, cara mempengaruhi orang dengan petunjuk atau perintah, tindkan yang menyebabkan orang lain bertindak atau merespons dan menimbulkan perubahan positif, kekuatan dinamis penting yang memotivasi dan mengkoordinasikan organisasi dalam rangka mencapai tujuan, kemampuan untuk menciptakan rasa percaya diri dan dukungan di antara bawahan agar tujuan organisasi dapat tercapai. Mintzberg (1983) dan Sutiadi (2001) mengemukakan bahwa peran kepemimpinan dalam organisasi adalah sebagai pengatur visi, motivator, penganalisis, dan penguasaan pekerjaan. Yasin (2001) mengemukakan bahwa keberhasilan kegiatan usaha pengembangan organisasi, sebagian besar ditentukan oleh kualitas kepemimpinan atau pengelolanya dan komitmen pimpinan puncak organisasi untuk investasi energy yang diperlukan maupun usaha-usaha pribadi pimpinan.

Pandji Anaroga dan Sri Suyati (1995) mengemukakan bahwa ada Sembilan peran kepemimpinan seorang dalam organisasi yaitu pemimpin sebagai perencana, pemimpin sebagai pembuat kebijakan, pemimpim sebagai ahli, pemimpin sebagai pelaksana, pemimpin sebagai pengendali, pemimpin sebagai pemberi hadiah dan hukuman, pemimpin sebagai teladan dan lambing atau symbol, pemimpin sebagai tempat menimpakan kesalahan, dan pemimpin sebagai pengganti peran lain.

Kepemimpinan merupakan kemampuan untuk mempengaruhi suatu kelompok kea rah tercapainya suatu tujuan. Kepemimpinan adalah pribadi yang dijalankan dalam situasi tertentu serta diarahkan melalui proses komunikasi kea rah pencapaian satu atau beberapa tujuan tertentu. Kepemimpinan menyangkut proses pengaruh social yang disengaja dijalankan oleh seseorang terhadap orang lain untuk menstruktur aktivitas dan pengaruh di dalam kelompok atau organisasi (Robbins, 2006). Kartini mengatakan bahwa fungsi kepemimpinan memandu, menuntun, membimbing, membangun, memberi atau membangun motivasi kerja, mengemudikan organisasi, menjaring jaringan komunikasi dan membawa pengikutnya kepada sasaran yang ingin dituju dengan ketentuan waktu dan perencanaan.

George R. Terry mengatakan bahwa kepemimpinan adalah hubunan antara seseorang dengan orang lain, pemimpin mampu memperngaruhi orang lain agar bersedia bekerja bersamasama dalam tugas yang berkaitan untuk mencapai tujuan yang diinginkan. Konz (1989) mendefenisikan kepemimpinan sebagai seni membujuk bawahan agar mau mengerjakan tugas-tugas dengan yakin dan semangat. Fieldler dalam Cahyono (2005) mengatakan bahwa kepemimpinan adalah pola hubungan 
antar individu yang menggunakan wewenang dan pengaruh terhadap orang lain atau sekelompok orang agar terbentuk kerja sama untuk menyelesaikan suatu tugas.

$$
\text { Menurut Yukl (1989), }
$$

kepemimpinan sebagai suatu proses pengaruh social yang sengaja dilakukan oleh seseorang terhadap orang lain untuk menstruktur aktivitas-aktivitas dan relasirelasi di dalam sebuah organisasi. Siagian dalam Waridin \& Masrukhin (2006) mengatakan baha peranan pimpinan dalam oragnisasi sangat sentral dalam pencapaian tujuan dari berbagai sarasarn yang ditetapkan sebelumnya. Kepemimpinan mempunyai fungsi sebagai penentu arah dalam pencapaian tujuan, wakil dan juru bicara organisasi, komunikator, mediator, dan integrator. Dalam konteks lain, Siagian mengatakan prilaku kepemimpinan memiliki kecenderungan pada dua hal yaitu konsiderasi atau hubungan dengan bawahan dan struktur inisiasi atau hasil yang dicapai. Kecenderungan kepemimpinan menggambarkan hubungan yang akrab dengan bawahan misalnya bersikap ramah, membantu dan membela kepentingan bawahan, bersedia menerima konsultasi bawahan, dan memberikan kesejahteraan. Kecenderungan seorang pemimpin memberikan batasan antara pemimpin dan bawahan dalam mencapai tujuan, memberikan instruksi pelaksanaan tugas (kapan, bagaimana, dan hasil apa yang akan dicapai).

C. Gaya Kepemimpinan

Kepemimpinan yang akan dilihat di sini adalah gaya kepeimpinan 
bawahannya yang bekerja dengan tepat waktu.

3. Gaya berorientasi pada tugas yaitu gaya kepemimpinan di mana seseorang pemimpin menuntut bahwahan untuk disiplin dalam hal pekerjaan atau tugas.

4. Gaya partisipasif yaitu gaya kepemimpinan di mana pemimpin mengharapkan saran-saran dan ide-ide dari bawahan sebelum mengambil keputusan.

\section{Tugas Kepemimpinan}

Tugas pokok seorang pemimpin yaitu melaksanakan fungsi-fungsi manajemen atau disebut juga fungsi menegerial yang terdiri dari: merencanakan, mengor-ganisasikan, menggerakkan, dan mengawasi. Terlaksananya tugas-tugas tersebut tidak dapat dicapai hanya oleh pimpinan seorang diri tetapi dengan menggerakan orang-orang yang dipimpinnya. Kemampuan mempengaruhi bawahan sangat diperlukan seorang pemimpin agar orang-orang yang dipimpin mau ikut serta bekerja secara efektif dan efisien. Seorang pemimpin di samping harus memiliki inisiatif dan kreatif harus selalu memperhatikan hubungan manusiawi.

Secara lebih terperinci tugastugas seorang pemimpin meliputi: pengambilan keputusan, menetapkan sasaran, menyusun kebijaksanaan, mengorganisasikan dan menempatkan pekerja, mengkoordinasikan kegiatankegiatan baik secara vertikal (antara bawahan dan atasan) maupun secara horizontal (antar bagian atau unit), serta memimpin dan mengawasi pelaksanaan pekerjaan.
Secara umum, tugas-tugas pokok pemimpin, yaitu sebagai berikut:

1. Melaksanaan fungsi managerial, yaitu berupa kegiatan pokok meliputi pelaksanaan, antara lain:

a. Penyusunan rencana.

b. Penyusunan organisasi, pengarahan organisasi, pengendalian dan penilaian.

c. Pelaporan.

2. Mendorong (memotivasi) bawahan untuk dapat bekerja dengan giat dan tekun.

3. Membina bawahan agar dapat memikul tanggung jawab tugas masing-masing secara baik.

4. Membina bawahan agar dapat bekerja secara efektif dan efisien.

5. Menciptakan iklim kerja yang baik dan harmonis.

6. Menyusun fungsi manajemen secara baik dan benar.

7. Menjadi penggerak yang baik dan dapat menjadi sumber kreativitas.

8. Menjadi wakil dalam membina hubungan dengan pihak luar (Siagian, 2002).

\section{E. Fungsi Kepemimpinan}

Fungsi pemimpin dalam suatu organisasi tidak dapat dibantah merupakan sesuatu fungsi yang sangat penting bagi keberadaan dan kemajuan organisasi yang bersangkutan. Pada dasarnya fungsi kepemimpinan memiliki 2 aspek yaitu sebagai berikut:

1. Fungsi administrasi, yakni mengadakan formulasi kebijaksanaan administrasi dan menyediakan fasilitasnya.

2. Fungsi sebagai top management, yakni mengadakan planning, organizing, 
staffing, directing, commanding, controlling, dsb.

Dalam upaya mewujudkan kepemimpinan yang efektif, maka kepemimpinan tersebut harus dijalankan sesuai dengan fungsinya. Sehubungan dengan hal tersebut, fungsi kepemimpinan berhubungn langsung dengan situasi sosial dalam kehidupan kelompok masing-masing yang mengisyaratkan bahwa setiap pemimpin berada di dalam, bukan berada di luar situasi yang sedang dihadapi. Pemimpin harus berusaha agar menjadi bagian di dalam situasi sosial kelompok atau organisasinya.

Pemimpin yang membuat keputusan dengan memperhatikan situasi sosial kelompok organisasinya, akan dirasakan sebagai keputusan bersama yang menjadi tanggung jawab bersama pula dalam melaksanakannya. Dengan demikian akan terbuka peluang bagi pemimpin untuk mewujudkan fungsifungsi kepemimpinan sejalan dengan situasi sosial yang dikembangkannya.

Fungsi kepemimpinan memiliki dua dimensi, yaitu (1) dimensi yang berhubungan dengan tingkat kemampuan mengarahkan (direction) dalam tindakan atau aktifitas pemimpin, yang terlihat pada tanggapan orang-orang yang dipimpinnya dan (2) dimensi yang berkenaan dengan tingkat dukungan (support) atau keterlibatan orang-orang yang dipimpin dalam melaksnakan tugastugas pokok kelompok atau organisasi, yang dijabarkan dan dimanifestasikan melalui keputusan-keputusan dan kebijakan pemimpin.

Sehubungan dengan kedua dimensi tersebut, secara operasional dapat dibedakan lima fungsi pokok kepemimpinan, yaitu:

\section{Fungsi Instruktif}

Pemimpin berfungsi sebagai komunikator yang menentukan apa (isi perintah), bagaimana (cara mengerjakan perintah), bilamana (waktu memulai, melaksanakan dan melaporkan hasilnya), dan dimana (tempat mengerjakan perintah) agar keputusan dapat diwujudkan secara efektif. Dalam fungsi ini, orang yang dipimpin hanyalah melaksanakan perintah. Fungsi ini berlangsung dan bersifat komunikasi satu arah. Pemimpin sebagai pengambil keputusan berfungsi memerintahkan pelaksanaan suatu pekerjaan pada orang-orang yang dipimpin atau diperintahnya. Fungsi ini berarti juga keputusan yang ditetapkan tidak akan ada artinya tanpa kemampuan mewujudkan atau menterjemahkannya menjadi instruksi/perintah yang baik sehingga dapat didengar dan mempunyai landasan operasional yang dimengerti bawahan. Selanjutnya perintah tidak akan ada artinya jika tidak dilaksanakan dengan baik oleh bawahan. Oleh karena itu sejalan dengan pengertian kepemimpinan, intinya adalah kemampuan pimpinan menggerakkan orang lain agar melaksanakan perintah, yang bersumber dari keputusan yang telah ditetapkan.

\section{Fungsi Konsultatif}

Pemimpin dapat menggunakan fungsi konsultatif sebagai komunikasi yang berlangsung dan bersifat dua arah. Hal tersebut digunakan manakala 
pemimpin dalam usaha menetapkan keputusan yang memerlukan bahan pertimbangan dan berkonsultasi dengan orang-orang yang dipimpinnya. Pelaksanaan fungsi ini sangat tergantung pada pihak pimpinan. Pada tahap pertama dalam usaha menetapkan keputusan, pemimpin kerap kali memerlukan bahan pertimbangan, yang mengharuskannya berkonsultasi dengan orang-orang yang dipimpinnya. Konsultasi ini dapat dilakukan secara terbatas hanya dengan orang-orang tertentu saja. Orang-orang yang menurut penilaian pemimpin mempunyai berbagai bahan informasi yang diperlukannya dalam menetapkan keputusan. Tahap berikutnya konsultasi dari pimpinan pada orangorang yang dipimpin dapat dilakukan setelah keputusan ditetapkan dan sedang dalam pelaksanaan. Konsultasi ini dimaksudkan untuk memperoleh masukan berupa umpan balik (feed back) yang dapat dipergunakan untuk memperbaiki dan menyempurnakan keputusan-keputusan yang telah ditetapkan dan dilaksanakan. Dengan menjalankan fungsi konsultatif dapat diharapkan keputusan pimpinan akan mendapat dukungan dan lebih mudah menginstruksikannya kepada bawahan, sehingga kepemimpinan berlangsung efektif. Fungsi konsultatif ini mengharuskan pimpinan belajar menjadi pendengar yang baik. Fungsi ini pasti dalam pelaksanaannya tidak akan semudah apa yang dikatakan, mengingat pemimpin lebih banyak menjalankan peranan sebagai pihak yang didengarkan, bukan pihak yang mendengarkan. Dalam hal ini, pemimpin harus meyakinkan dirinya bahwa dari siapa pun juga selalu mungkin diperoleh gagasan, inspirasi, aspirasi, saran yang konstruktif bagi pengembangan kepemimpinanya.

\section{Fungsi Partisipasitif}

Pemimpin dalam menjalankan fungsi partisipasi berusaha mengaktifkan orang-orang yang dipimpinnya, baik dalam pengambilan keputusan maupun dalam pelaksanaannya. Setiap anggota kelompok memperoleh kesempatan yang sama untuk berpartisipasi dalam melaksanakan kegiatan yang dijabarkan dari tugas-tugas pokok, sesuai dengan posisi masing-masing. Fungsi ini tidak sekedar berlangsung dan bersifat dua arah, tetapi juga berwujud pelaksanaan hubungan manusia yang efektif, antara pemimpin dengan sesama orang yang dipimpinnya, baik dalam keikutsertaan mengambil keputusan maupun dalam melaksanakannya. Fungsi partisipasi hanya akan terwujud jika pemimpin mengembangkan komunikasi yang memungkinkan terjadinya pertukaran pendapat, gagasan dan pandangan dalam memecahkan masalah-masalah. Komunikasi ini, bagi pimpinan akan dapat dimanfaatkan untuk mengambil keputusan-keputusan. Sehubungan dengan itu musyawarah menjadi penting, baik yang dilakukan melalui rapat-rapat mapun saling mengunjungi pada setiap kesempatan yang ada. Musyawarah sebagai kesempatan berpartisipasi, harus dilanjutkan berupa partisipasi dalam berbagai kegiatan melaksanakan program sebuah organisasi. 
4. Fungsi Delegasi

Pemimpin dalam menjalankan fungsi delegasi, pemimpin memberikan pelimpahan wewenang membuat atau menetapkan keputusan. Fungsi delegasi sebenarnya adalah kepercayaan seorang pemimpin kepada orang yang diberi kepercayaan untuk pelimpahan wewenang dengan melaksanakannya secara bertanggungjawab. Fungsi pendelegasian ini, harus diwujudkan karena kemajuan dan perkembangan kelompok tidak mungkin diwujudkan oleh seorang pemimpin seorang diri. Fungsi ini dilaksanakan dengan memberikan limpahan wewenang membuat/menetapkan keputusan, baik melalui persetujuan maupun tanpa persetujuan dari pimpinan. Fungsi ini mengharuskan pemimpin memilahmilah tugas pokok organisasi dan mengevaluasi yang dapat dan tidak dapat dilimpahkan pada orang-orang yang dipercayainya. Fungsi delegasi pada dasarnya berarti kepercayaan, pemimpin harus bersedia dapat mempercayai orang-orang lain, sesuai dengan posisi/jabatannya, apabila diberi pelimpahan wewenang. Sedang penerima delegasi harus mampu memelihara kepercayaan itu, dengan melaksanakannya secara bertanggung jawab. Fungsi pendelegasian harus diwujudkan seorang pemimpin karena kemajuan dan perkembangan kelompoknya tidak mungkin diwujudkannya sendiri. Pemimpin seorang diri tidak akan dapat berbuat banyak dan bahkan mungkin tidak ada artinya sama sekali. Oleh karena itu sebagian wewenangnya perlu didelegasikan pada para bawahannya, agar dapat dilaksanakan secara efektif dan efisien.

\section{Fungsi Pengendalian}

Kepemimpinan yang efektif harus mampu mengatur aktifitas anggotanya secara terarah dan dalam koordinasi yang efektif, sehingga memungkinkan tercapainya tujuan bersama secara maksimal. Dalam melaksanakan fungsi pengendalian, pemimpin dapat mewujudkan melalui kegiatan bimbingan, pengarahan, koordinasi, dan pengawasan. Fungsi pengendalian merupakan fungsi kontrol. Fungsi ini cenderung bersifat satu arah, meskipun tidak mustahil untuk dilakukan dengan cara komunikasi secara dua arah. Fungsi pengendalian bermaksud bahwa kepemimpinan yang sukses atau efektif mampu mengatur aktivitas anggotanya secara terarah dan dalam koordinasi yang efektif, sehingga memungkinkan tercapainya tujuan bersama secara maksimal. Dalam kegiatan tersebut pemimpin harus aktif, namun tidak mustahil untuk dilakukan dengan mengikutsertakan anggota kelompok/ organisasinya (Kartini Kartono, 1994).

\section{METODE PENELITIAN}

Penelitian ini bertujuan untuk mengukur tingkat kepuasan kepemimpinan Ketua Yayasan Seri Amal Medan. Jenis penelitian ini termasuk deskriptif kuantitatif. Penelitian dilakukan pada bulan Nopember 2020 kepada Kepala Sekolah yang di unit TK, SD, SMP, dan SMA yang dikelola Yayasan Seri Amal Medan, Jalan Hayam Wuruk 11 Medan. Jumlah responden 
adalah 11 orang. Data dikumpulkan dengan menggunakan angket dengan lima option (sangat setuju, setuju, kurang setuju, tidak setuju, dan sangat tidak setuju) yang berjumlah 35 pernyataan yang dihubungkan dengan tugas, fungsi, peran, dan kepribadian seorang pemimpin berdasarkan kerangka teoretik kepemimpinan. Data dianalisis dengan mentabulasi dan menjumlahkan setiap pilihan maupun secara keseluruhan dengan kriteria berikut: 90-100 (sangat baik), 80-89 (baik), 65-79 (cukup baik), di bawah 65 (kurang).

\section{HASIL DAN PEMBAHASAN}

\section{A. Hasil Penelitian}

\begin{tabular}{|c|c|c|}
\hline & Bithoget & \\
\hline & 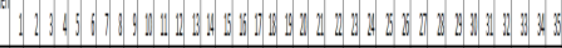 & TVA. 789 \\
\hline & 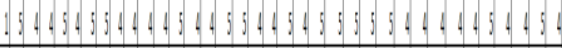 & 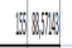 \\
\hline & 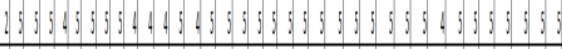 & 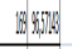 \\
\hline & 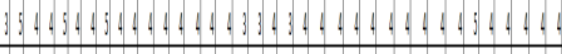 & (101006. \\
\hline & 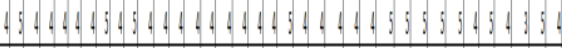 & 2060 \\
\hline & 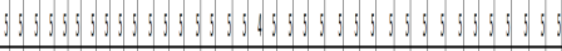 & 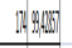 \\
\hline & 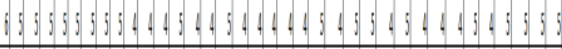 & 1915\%: \\
\hline & 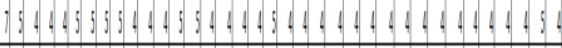 & Ba, \\
\hline & 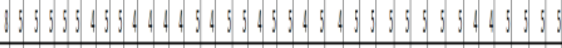 & 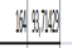 \\
\hline & 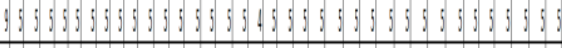 & 104,467 \\
\hline & 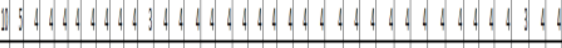 & 38,46 \\
\hline & 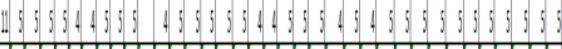 & 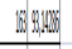 \\
\hline & (5) (9):39) & 173 \\
\hline & 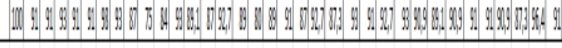 & 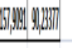 \\
\hline
\end{tabular}

pernyataan yang dinilai responden dengan sangat baik (SB) yaitu yang skornya 5055. Pernyataan itu adalah nomor 1, 2, 3, 4, 5, 6, 7, 8, 12, 15, 19, 21, 24, 25, 26, 27, 29, 30, 31, 32, 34, dan 35. Pernyataan lain dinilai responden dengan baik (B) yaitu nomor $9,10,11,13,14,16,17,18,22,28$, dan 33. Jumlah total skor responden adalah 1741 dibandingkan dengan skor tertinggi 1925. Karena itu, $1741: 1925$ x $100=90,44$. Nilai 90,44 dikonsultasikan kepada kiteria di atas ada pada rentang nilai sangat baik.

\section{B. Pembahasan Hasil}

Hasil penelitian yang ditemukan di atas didasarkan pada pengalaman langsung responden dari berbagai kegiatan, pertemuan (rapat) rutin, dan pemaparan program yang dilakukan oleh Pemimpin Yayasan Seri Amal. Hal ini biasa dilihat dari gaya kepemimpinan, program yang dibuat setiap tahun, adaptasi perubahan dan pengembangan dalam dunia pendidikan, dan peningkatan terhadap penghargaan dan kesejehateraan struktural sekolah, guru, dan tenaga kependidikan (karyawan). Skor penilaian yang paling rendah oleh responden yaitu pernyataan nomor 17 dan 10 . Pernyataan nomor 17 berkaitan dengan pemimpin berkonsultasi kepada bawahannya sebelum mengambil keputusan. Rendahnya skor ini diakibatkan karena kepala sekolah hanya sebagian kecil berkonsultasi dengan pemimpin yayasan karena kepala sekolah adalah pelaksana kebijakan yayasan. Pimpinan Yayasan lebih banyak berkonsultasi dengan sesama Pengurus Yayasan. Skor pernyataan nomor 10 dapat saja disebabkan karena pemikiran subyektif yang dimiliki sebagian kepala sekolah karena tidak secara langsung memahami sistem dan hasil perekrutan yang dilakukan Pengurus Yayasan.

\section{KESIMPULAN DAN SARAN}

\author{
p-ISSN 2648-8600 \\ e-ISSN 2745-410X \\ Volume 3 Nomor 2 Desember2020
}


Tingkat kepuasan kepemimpinan Ketua Yayasan Seri Amal Medan oleh Kepala Sekolah di unit TK, SD, SMP, dan SMA yang dikelola Yayasan Seri Amal Medan tergolong sangat baik yaitu skor 90,44. Hasil penilaian ini dianggap reliabel karena tidak memiliki perbedaan (rentang) nilai yang tinggi oleh setiap responden. Penilian ini perlu diperluas dengan melibatkan wakil kepala sekolah dan pengurus yang lain. Selain itu, pengukuran tingkat kepuasan kepemimpinan ini dapat dilakukan untuk kepala sekolah di setiap unit sekolah yang dikelola oleh Yayasan Seri Amal.

\section{DAFTAR PUSATAKA}

Dubrin, Andrew J. 2005. Leadership (Terjemahan). Jakarta: Prenada Media.

Cahyono, Budi. 2005. "Pengaruh Budaya

Organisasi, Kepemimpinan, dan Motivasi." Jurnal Riset Bisnis Indonesia, Vol. 1 Nomor 1 , Januari 2005.

Fuad, Mas'ud. 2004. Survai Diagnosis Organisasional. Semarang: Penerbit Universitas Diponegoro.

Handoko. T. Hani, 1995, Manajemen, Edisi 2 Yogyakarta : BPFE

Konz, Harold. 1989. "Management", $2^{\text {nd }}$ edition, Prenctice Hall.

Mintzberg, Henry. 1983. "Structure in Five, Designing Effecitive Organizations", Prentice Hall.
Panji, Anaroga dan Sri Suyati. 1995. Perilaku Keorganisasian. Jakarta: Pustaka Jaya.

Pusat Bahasa Departemen Pendidikan Nasional. 2008. Kamus Besar Bahasa Indonesia. Jakarta: PT Gramedia Pustaka Utama.

Robbin, Stephen P. 2006. Perilaku Organisasi (terjemahan). Jakarta: PT Indeks.

Siagian, Sondang P. 2002. Kiat Meningkatkan Produktivitas Kerja. Jakarta: Rineka Cipta.

Suit, Yusuf \& Almasdi. Aspek Sikap Mental dalam Sumber Daya Manusia. Jakarta : Ghalia Indonesia : 1996

Sutiaadi, H. Noerwijati dan Arman Thoyib. 2001. "Motivasi Karyawan dan Aktivitas Manajerial Kepemimpinan: Pengaruhnya terhadap Kinerja Karyawan". Jurnal Aplikasi Manajemen, Vol. 94, halaman 95.

Terry, George. 1985. Manajemen, edisi terjemahan. Jakarta: Penerbit Ghalia Indonesia.

Undang-undang Republik Indonesia Nomor 16 Tahun 2001 dan Nomor 28 Tahun 2004 tentang Yayasan.

Waridin dan Masrukhin, 2006. "Pengaruh Motivasi Kerja, Kepuasan Kerja, Budaya Organisasi dan Kepemimpinan Terhadap Kinerja Pegawai". Ekobis Vol. 7 , No. 2 
Yasin. 2001. Kepemimpinan Manajer:

Eksistensi dalam Perilaku

Organisasi. Jakarta: Rajawali

Press.

Yukl G.A. (1989), Leadership in

Organization ( $2^{\text {nd }}$ ed) englewod

Cliffs N.J : Prentice Hall 